\title{
EFFECTS OF CANNABIS SATIVA EXTRACT AND ITS COMBINATION WITH VITAMIN-C ADMINISTRATION ON HISTOMORPHOLOGICAL CHANGES IN THE TESTICULAR TISSUE OF MALE MICE
}

\author{
Zahid Sarfaraz Khan ${ }^{1,2 \otimes}$, Muhammad Saeed ${ }^{2}$, Syed Muhammad Hamid ${ }^{3}$
}

\begin{abstract}
OBJECTIVE: To observe morphological changes in testicular tissue of adult male $\mathrm{BALB} / \mathrm{c}$ mice after administration of Cannabis sativa extract and to investigate the protective role of vitamin- $C$ against cannabis-induced histopathological changes.
\end{abstract}

METHODS: Eighteen BALB/c mice ( $3 \mathrm{l}-40 \mathrm{~g}$ ) were divided into 3 groups. GroupI was control group, Group-II received oral cannabis extract $(14 \mathrm{mg} / \mathrm{kg})$ and Group-III received cannabis extract $(14 \mathrm{mg} / \mathrm{kg})$ orally along with vitamin-C (100 $\mathrm{mg} / \mathrm{kg}$ ) for 45 days. At the end of experiment, variations in body weight, testicular weight and histological changes in testicular tissues of mice were observed.

RESULTS: Average increase in weight was $7.000 \pm 0.77 \mathrm{gm}, 4.833 \pm 0.87 \mathrm{gm} \&$ $5.833 \pm 0.79 \mathrm{gm}$ in group-I, group-II and group-III respectively. Weight reduction in right and left testis was $42.30 \pm 0.465 \mathrm{mg}$ and $42.45 \pm 0.424 \mathrm{mg}$ in group-l, $38.85 \pm 0.523 \mathrm{mg}$ and $39.35 \pm 0.520 \mathrm{mg}$ in group-II, and $42.38 \pm 0.465 \mathrm{mg}$ and $42.23 \pm 0.424 \mathrm{mg}$ in group-III animals respectively $(p<0.0 \mathrm{I})$. Mean seminiferours epithelium thickness was $4.367 \pm 0.302 \mu \mathrm{m}$ in group-II, $5.683 \pm 0.104 \mu \mathrm{m}$ and $6.417 \pm 0.116 \mu \mathrm{m}$ in Group-I and group-III respectively $(\mathrm{p}<0.00 \mathrm{I})$. Average germ cells count (cells/tubule) in group-Il was reduced $(256.25 \pm 6.58)$ as compared to group-I (373.50 \pm 4.063$)$ and group-III $(366.25 \pm 3.442)$. Histological changes observed after the treatment were decreased height of germinal epithelium, basal lamina disruption, seminiferous tubules shrinkage, scanty cytoplasm with shrunken nuclei and germinal epithelium detachment from basal lamina in group-II animals as compared to group-I and group-III.

CONCLUSION: The cannabis administration significantly declines the weight, size of testes, germ cells count and the height of seminiferours epithelium in animals. Vitamin- $\mathrm{C}$ had a protective role on cannabis induced toxic changes in the testes of the mice.

KEY WORDS: Cannabis (MeSH); Cannabis Sativa (MeSH); Vitamin C (MeSH); Ascorbic Acid (MeSH); Fertility (MeSH); Testes (MeSH); Histology (MeSH); Seminiferous Tubules (MeSH); Spermatogenesis (MeSH).

THIS ARTICLE MAY BE CITED AS: Khan ZS, Saeed M, Hamid SM. Effects of Cannabis sativa extract and its combination with vitamin-c administration on histomorphological changes in the testicular tissue of male mice. Khyber Med Univ J 2020; I 2(3):229-33. DOI: 10.35845/kmuj.2020. I 9648.

\section{INTRODUCTION}

$\mathrm{C}_{\mathrm{cos}}$ annabis sativa is the most commonly used illegal drug throughout the globe.' It is a complex plant containing more than 400 chemical entities and more than 60 belong to cannabinoid. ${ }^{1,2}$ The main ingredient having psychoactive activity is marijuana THC (delta-9tetrahydrocannabinol) and its amount determines its strong effects. ${ }^{3}$ Marijuana smoking disrupts the hormonal balance of both male and female. Higher usage of cannabis responsible for various endocrine changes such as, reduced testosterone levels, decreased sperm counts in males, declined luteinizing hormone and prolactin levels during luteal phase in females which ultimately leads to shorter periods and more anovulatory cycles. ${ }^{4}$ Studies in male rodents exposed to marijuana show significant decrease in both
I. Department of Anatomy, Khyber Girls Medical College, Peshawar, Pakistan.

2. Department of Anatomy, Peshawar Medical College, Peshawar, Pakistan.

3. Research Evaluation Unit, College of Physicians and Surgeons Regional Center Peshawar, Peshawar, Pakistan.

Email凶: zahidsurfarazmc@gmail.com Contact \#: +92-314-9004008

$\begin{array}{ll}\text { Date Submitted: } & \text { August } 27,2019 \\ \text { Date Revised: } & \text { July } 07,2020 \\ \text { Date Accepted: } & \text { July } 18,2020\end{array}$

testosterone and gonadotropins with administration of THC, which is due to inhibition of the gonadotropic releasing hormone $(\mathrm{GnRH})$ in the hypothalamus. Marijuana has also been associated with the development of gynecomastia in both men and rodents. ${ }^{5}$ Researches also indicate that with cannabis extract administration, there is a decrease in the size of testes, shrinkage of the seminiferous tubules, epididymis, vasdeference and it affects the process of spermatogenesis in experimental animals. ${ }^{6}$

Vitamin-C (ascorbate) is a strong watersoluble antioxidant in biological fluids, physiologically relevant reactive oxygen (RO) and nitrogen species. 'Vitamin-C is nutritive anti-oxidants, which can neutralize the free radicals and react directly with peroxides and execute an important antioxidant function in humans and animals. ${ }^{7}$ Additionally, it is involved in the regeneration of other small antioxidants molecule ( $\alpha$ tocopherol, glutathione, urate, and $\beta$ carotene) and its potential pro-oxidant activity also been well documented. ${ }^{1,8}$

This study was designed to compare the morphological changes caused by Cannabis sativa extract with the protective role of vitamin- $C$ against cannabis induced histopathological changes in the testes of adult male $\mathrm{BALB} / \mathrm{c}$ mice strain. 
TABLE I: BODY WEIGHT VARIATION AND BODY WEIGHT GAIN IN DIFFERENT EXPERIMENTAL GROUPS

\begin{tabular}{|l|c|c|c|c|c|c|}
\hline \multirow{2}{*}{ Groups } & \multicolumn{4}{|c|}{ Experimental Days } & \multicolumn{2}{c|}{ Body Weight Gain } \\
\cline { 2 - 7 } & I & I5 & $\mathbf{3 0}$ & $\mathbf{4 5}$ & gm & $\%$ \\
\hline Group I (Control) & $37.33 \pm \mathrm{I} . \mathrm{II}$ & $42.50 \pm 0.7 \mathrm{I}$ & $43.00 \pm 0.93$ & $44.33 \pm 0.88$ & $7.000 \pm 0.77$ & $19.02 \pm 2.40$ \\
\hline Group II (Cannabis) & $35.50 \pm \mathrm{I} .76$ & $38.67 \pm \mathrm{I} .74$ & $39.17 \pm 1.62$ & $40.33 \pm 1.62$ & $4.833 \pm 0.87$ & $14.0 \mathrm{I} \pm 2.87$ \\
\hline Group III (Vit-C+Cannabis) & $34.17 \pm 0.70$ & $38.50 \pm \mathrm{I} .45$ & $39.17 \pm 1.57$ & $40.00 \pm 1.36$ & $5.833 \pm 0.79$ & $16.95 \pm 2.10$ \\
\hline
\end{tabular}

\section{TABLE II: TESTICULAR WEIGHT (RIGHT \& LEFT) OF DIFFERENT EXPERIMENTAL GROUPS AT 45 DAYS}

\begin{tabular}{|l|c|c|}
\hline \multicolumn{1}{|c|}{ Treatment Groups } & Weight of right testis (mg) & Weight of left testis (mg) \\
\hline Group I (Control) & $42.30 \pm 0.465 \mathrm{mg}$ & $42.45 \pm 0.424 \mathrm{mg}$ \\
\hline Group II (Cannabis) & $38.85 \pm 0.523 \mathrm{mg}$ & $39.35 \pm 0.520 \mathrm{mg}$ \\
\hline Group III (Vit-C+Cannabis) & $42.38 \pm 0.465 \mathrm{mg}$ & $42.23 \pm 0.424 \mathrm{mg}$ \\
\hline
\end{tabular}

\section{METHODS}

Eighteen $\mathrm{BALB} / \mathrm{c}$ mice $(3 \mathrm{I}-40 \mathrm{~g})$ were obtained from the National Institute of Health, Islamabad, Pakistan. They were housed at $18-26^{\circ} \mathrm{C}\left(68-75.2^{\circ} \mathrm{F}\right)$ temperature with relative humidity of $40-70 \%$. Study animals were provided with food and water ad-libitum and maintained at a 12/12 hours light/dark cycle. Light within the cages was diffuse and uniform to avoid glare, heat clusters and fluctuating lighting conditions. All experiments were examined approved by Ethical Committee of the Department of Pharmacy, University of Peshawar, Pakistan and conducted according to the principles of "United Kingdom Animal Scientific Procedure Act 1986".

For the collection and extraction of Cannabis sativa leaves, the procedure of Ullah et al. ${ }^{9}$ were followed. Female plants of Cannabis sativa were collected at a farm with permission from Pladura area of Charsadda at its bloom season. The plant was authenticated by personnel of the Department of Botany, University of Peshawar, Peshawar. Leaves and flowering tops were separated. The plant material was shad dried and coarsely grinded. The grinded plant material was then extracted with $\mathrm{n}$-hexane to obtain a yield of $500 \mathrm{gm}$. The extract was then filtered and concentrated under reduced pressure at $45^{\circ} \mathrm{C}$ in a rotary evaporator. A yield of $50 \mathrm{ml}$ was obtained. For oral administration, the extract was dissolved in absolute ethanol, mixed with emulsifier and made the volume with distilled water in such a way that the final mixture consists of ethanol: emulsifier: distilled water in a ratio of 5:5:90.

After one-week acclimatization to their new environment with standard diet and water given ad-libitum, the 18 male $\mathrm{BALB} / \mathrm{c}$ mice were randomly divided in a blinded fashion into 3 oral treatment groups. All animals were kept in the animal house under standard conditions at a room temperature $\left(18^{\circ} \mathrm{C}\right.$ to $\left.26^{\circ} \mathrm{C}\right)$ for 45 days duration. The details of the group as follows:

Group I (control): Consisted of 6 mice that received solvent system, plain water and commercial standard mash feed orally for 45 days.

Group II: Consisted of 6 mice and received cannabis extract $(14 \mathrm{mg} / \mathrm{kg})$ orally once daily for a period of 45 days.

Group III: Consisted of 6 mice that were given cannabis extract at a dose of $14 \mathrm{mg} / \mathrm{kg}$ orally once daily for period of 45 days along with vitamin-C $100 \mathrm{mg} / \mathrm{kg}$ of body weight.

The concentration of $\mathrm{I} \mathrm{mg} / \mathrm{ml}$ of Cannabis sativa solution was administered at a dose of $14 \mathrm{mg} / \mathrm{kg}$ according to Dixit ${ }^{10}$ and $4 \mathrm{mg} / \mathrm{ml}$ of vitamin-C was dissolved in normal saline and, was administered at a dose of 100 $\mathrm{mg} / \mathrm{kg}$ according to Hsu and Guo." Cannabis sativa was administered orally through an oral gavage tube. At the end of the experiment, after 45 days, the control and experimental animals were sacrificed by cervical dislocation. After cervical dislocation, testes from each animal were removed and the weight of animal body and their testes were recorded as quickly as possible to avoid any pathological changes due to necropsy and were transferred to labelled jars containing 10\% neutral buffered formalin for preservation. After fixation the testicular tissue samples were dehydrated using increasing grades of alcohol, cleared in xylene and embedded in paraffin. Tissue sections $(5 \mu \mathrm{m})$ were cut using a microtome and stained with Harris Hematoxylin and eosin (H \& E) and mason trichrome for histological analysis. Photomicrographs of tissues sections were taken on a digital camera attached with the microscope. Quantitative methods were used for the evaluation of all slides. Parameters including height of the germinal epithelium and germ cell count were noted. For the calculation of height of germinal epithelium, ocular micrometer was used, which was calibrated with stage micrometer. ${ }^{13}$

Paired testicular/body weight ratio (PTWR) was determined by dividing the total weight of the two testes by the final body weight of the animal.

Data was analyzed with different tests using Statistical Package for Social Science (SPSS) for window version 13 . Data were presented as the mean \pm SEM. P-Value $\leq 0.05$ were measured statistically significant.

\section{RESULTS}

The average weight of animal at the beginning of the study and at the end of the study is listed in Table I. However, there was an increase in relative body weights of all the groups. Average increase in weight of control group I was $7.000 \pm 0.77 \mathrm{gm}$, in group II was $4.833 \pm 0.87 \mathrm{gm}$ and in group III was $5.833 \pm 0.79$ gm respectively (Table I). 
Significant reduction was observed in the weight of right $(38.85 \pm 0.523 \mathrm{mg})$ and left $(39.35 \pm 0.520 \mathrm{mg})$ testis of group-II animals as compared to right $(42.30 \pm 0.465 \mathrm{mg})$ and left $(42.45 \pm 0.424 \mathrm{mg})$ testis of animals in group-I (Table II).

Histological evaluation of testis in solvents systems, cannabis alone and cannabis plus vitamin- $C$ groups after 45 days by $H$ \& $E$ method, for routine histological studies and Masson Trichrome for observing fibrosis are presented in Figure 3. Histological changes observed after the treatment were decreased height of germinal epithelium, basal lamina disruption, seminiferous tubules shrinkage, scanty cytoplasm with shrunken nuclei and germinal epithelium detachment from basal lamina in group-II animals as compared to group-l and group-III.

A significant decrease $(p<0.00 \mathrm{I})$ was observed in the thickness of germinal epithelium of cannabis alone (4.367 \pm 0.302$)$ animals as compared to group I $(5.683 \pm 0.104)$ animals (Table III).

Mean germ cells count (cells/tubule) in group-II was $256.25 \pm 6.58$ as compared to $373.50 \pm 4.063$ and $366.25 \pm 3.442$ in Group-I and group-III respectively $(p<0.00 I)$.

\section{DISCUSSION}

The present study using male BALB/C mice yielded information on the toxic effects of Cannabis sativa on the seminiferous tubules of the testes and the protective role of the vitamin-C against cannabis induced testicular toxicity. The findings revealed that, after 45 days of the experiment our study did not reveal any significant decrease in the mean body weight of group II (cannabis alone) animals. These results were supported by the previously published study in which cannabis was administered to rats in the dose of 20 ( $\mathrm{mg} / \mathrm{kg} /$ body weight) for $2 \mathrm{l}$ consecutive days. ${ }^{14}$ However, findings of this study were deviated from the studies conducted by Lotfi et al. ${ }^{15}$, and Banerjee et al. ${ }^{16}$ Author reported the significantly decreased in body weight of cannabis group as compared to the control group animals. The variation in the result of this study from previously conducted studies may be due to the use of lower cannabis dose ( $14 \mathrm{mg} / \mathrm{kg} /$ body weight).
A

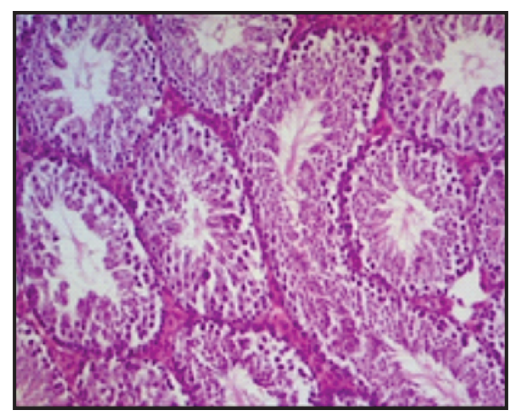

D

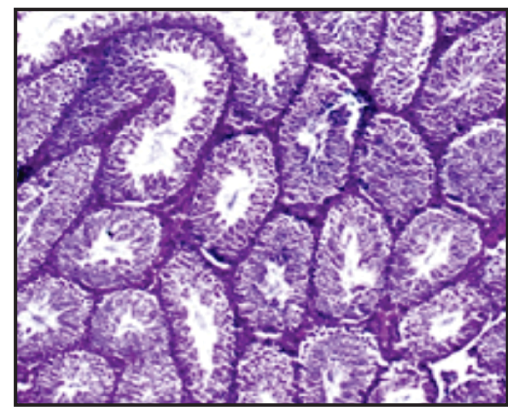

B

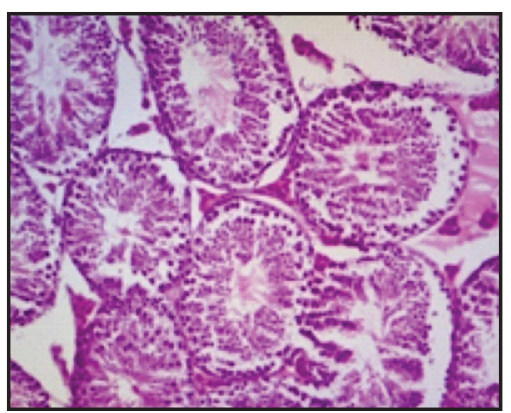

E

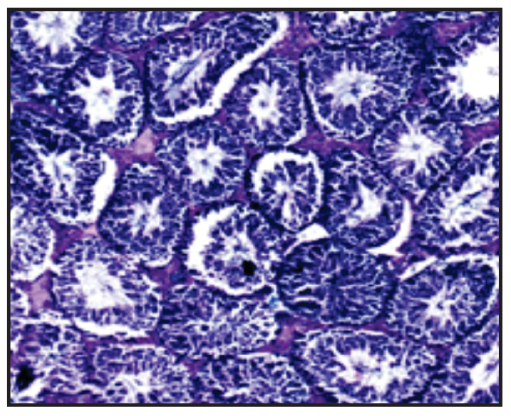

C

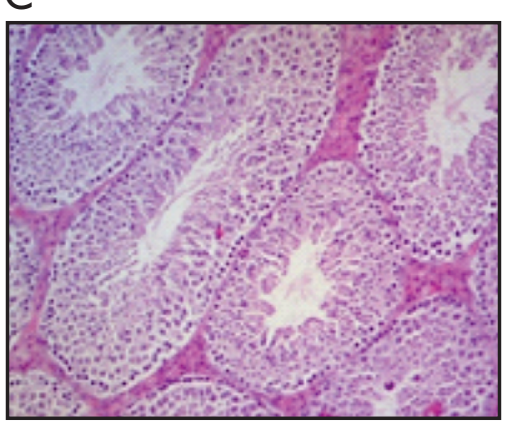

$\mathrm{F}$

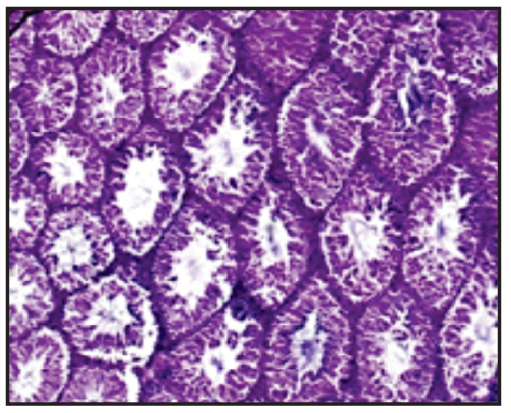

Figure 3: Histological evaluation of testis in solvents systems, cannabis and cannabis plus Vit- $\mathrm{C}$ after 45 days. A. Photomicrograph of $5 \mu \mathrm{m}$ thick $\mathrm{H}$ and $\mathrm{E}$ stained section of testis of a control group showing normal histological appearance of seminiferous tubules. B: $\mathrm{H}$ and E stained section of testis of a group II (cannabis only) showing histopathological changes (changes in Morphology, thickness, number of spermatogenic cells and damage in basement membrane or basal lamina of semiferous tubules) in the germinal epithelium of seminiferous tubules. C: $\mathrm{H}$ and $\mathrm{E}$ stained section oftestis of a grouplll (cannabis plus Vitamin-C) showing normal histological appearance of seminiferous tubules. D. Photomicrograph of $5 \mu \mathrm{m}$ thick Masson trichrome stained section of testis of a control group showing normal histological appearance of seminiferous tubules. E. Masson trichrome stained section oftestis of a group II (cannabis only) showing histopathological changes (changes in Morphology, thickness, number of spermatogenic cells and damage in basement membrane or basal lamina of semiferous tubules) in the germinal epithelium of seminiferous tubules. F. Masson trichrome stained section oftestis of a group III (cannabis plus Vitamin-C) showing normal histological appearance of seminiferous tubules. 
This study regarding the protective role of vitamin- $C$ suggested that animals in group III were treated with vitamin-C retained the body weight loss, which was induced by chronic administration of cannabis. However, this protection in body weight was not statistically significant. Our study have analogous results with the studies conducted by Mandal and Das ${ }^{17}$ and Nwangwa et al. ${ }^{14}$ who showed that treatment with vitamin-C at a dose of $(100 \mathrm{mg} / \mathrm{kg} /$ body weight) for 21 consecutive days restored the cannabis induced decrease in body weight.

The finding revealed a reduction in testes size and weight of group II (cannabis alone) animals and thus the mean weight of paired testes of these animals were significantly less than those of control group. The reason of reduction of testes weight of group II animals could have been due to degeneration and shrinkage of germinal epithelium of seminiferous tubules of the testes. Therefore, finding of this study was in accord with the result of a study conducted by Bergamaschi MM et al. ${ }^{18}$ in which the effects of cannabis oral treatment at doses of 30,100 , or 300 ( $\mathrm{mg} / \mathrm{kg} /$ body weight) daily for 90 days, observed reduction in testicular weight. Furthermore, the present study also supports the study conducted by Banerjee et al. ${ }^{16}$ who administered cannabis to adult male mice at a dose 3 or $6(\mathrm{mg} / \mathrm{kg} /$ body weight) daily orally for 36 days and revealed that mice exposed to cannabis showed a significant decline in the weight of testes with increasing dose of cannabis. The reduction in the testicular weight with the higher dose was greater than with the lower dose of cannabis. They correlated the reduction of testes weight with the decrease in number of germ cells.

This study with regard to the protective role of vitamin- $C$ revealed that the testicular weight was reduced in treated group II (cannabis only) and was significantly restored in group III (cannabis along with vitamin-C). Comparable results with this study also reported by Mandal and Das ${ }^{17}$ and Nwangwa et al. ${ }^{14}$ whose observed that treatment with vitamin- $C$ in the dose of ( $100 \mathrm{mg} / \mathrm{kg} /$ body weight) for 21 consecutive days protected the cannabis induced decrease in testicular weight.

The recent study reported that testes of the cannabis treated animals were associated with degeneration and separation of germinal epithelium from the basal lamina and sloughing of degenerated germ cells into the lumen of seminiferous tubules. Similar finding was also reported by Tijani AA et al. ${ }^{19}$, Yassa HA et al. ${ }^{20}$ and Banerjee et al. ${ }^{16}$. They found that cannabis exposure was associated with tubular degeneration, characterized by germinal epithelium degeneration. The present study revealed that testes of the cannabis treated animals were associated with the loss and degeneration of Ledig cells in the interstitial connective tissue and widening of the intertubular space. These findings also supported by the study of Banerjee et.al ${ }^{16}$ and Khan and Hassan. ${ }^{21}$ A decrease in height of the seminiferous epithelium of group II (cannabis alone) as compared to control group and this change was not observed in group III. Our finding is in accord with the result of a studies conducted by Reuhl J et al. ${ }^{22}$ Nwagwa et al..$^{14}$ and Lotfi et al. ${ }^{15}$ who showed decrease in height of seminiferous epithelium.

The germ cells count in the cannabis alone (group II) was markedly decreased as compared to control (group I). A study conducted by Khan and Hassan ${ }^{21}$ and Lotfi et al. ${ }^{15}$ also reported a decreased in germ cell count. Whereas, in group III there was recovery of germ cells, after being treated with antioxidants (Vitamin-C) along with cannabis during experiment. These findings were supported by Yasmina et al. ${ }^{7}$ and Nwagwa et al. ${ }^{14}$ whose showed that treatment with vitamin- $C$ had restored the cannabis induced decrease in germ cells in terms of count. Therefore, our current study has similar results which showed that treated animals with Vitamin-C significantly protected cannabis induced decrement germ cells count.

\section{CONCLUSION}

Administration of cannabis had toxic effect on mouse testes which were significantly prevented by the concurrent administration of Vitamin-
C. The cannabis administration significantly declines the weight, size of testes, germ cells count and the height of seminiferours epithelium in animals. However, cannabis along with vitamin$\mathrm{C}$ administration significantly restored the weight, size of testes, germ cells count and the height of seminiferours epithelium in animals.

\section{REFERENCES}

I. Alagbonsi IA, Olayaki LA, Salman TM. Melatonin and vitamin C exacerbate Cannabis sativa-induced testicular damage when administered separately but ameliorate it when combined in rats. J Basic Clin Physiol Pharmacol 2016;27:277-87. DOI: 10.15I5/ jbcpp-20 I5-006 I.

2. Pertwee RG, Howlett A, Abood ME, Alexander SP, Di Marzo V, Elphick $M R$, et al. International Union of Basic and Clinical Pharmacology. LXXIX. Cannabinoid receptors and their ligands: beyond $C B I$ and $C B 2$. Pharmacol Rev 2010;62:588-63।. DOI: I0.I I 24/pr. I 10.003004.

3. Hart CL, Van Gorp W, Haney M, Foltin RW, Fischman MW. Effects of acute smoked marijuana on complex cognitive performance. Neuropsychopharmacology 200I;25:757-65. DOI: 10.1016/ S0893-I33X(0I)00273-I.

4. Ramström J. Adverse health consequences of cannabis use. National Institute of Public Health, Sweden; 2004. [Accessed on: July 05, 2019]. Available from URL: https://www.drugsandalcohol.ie/39 25/I/2915-3089.pdf

5. Nahas G. Biomedical aspects of cannabis usage. Bull Narc 1977;29: 13-27.

6. Mandal TK, Das NS. Testicular toxicity in cannabis extract treated mice: association with oxidative stress and role of antioxidant enzyme systems. Toxicol Ind Health 20 10;26:1।-23. DOI:10.1177/ 0748233709354553.

7. Yasmina M, Abdennour C. Influence of vitamin $C$ on testicular functions of domestic rabbit Oryctolagus cuniculus under mercury exposure. 
EurJ Sci Res 2008;22: 197-204.

8. Halliwell B. Commentary: vitamin C: antioxidant or pro-oxidant in vivo? Free Radic Res 1996;25:43954.

9. Ullah I, Subhan F, Rauf K, Badshah A, Ali G. Role of gastrointestinal motility/gastric emptying in cisplatin-induced vomiting in pigeon. Afr J Pharma Pharmacol 20I2;6:2592-9.

10. Dixit V. Effects of cannabis sativa extract on testicular function of presbytis entellus entellus. Planta Med | 98I;4I:288-94. DOI: 10. 1055/s-2007-97|7|6.

II. Hsu PC, Guo YL. Antioxidant nutrients and lead toxicity. Toxicology 2002; I80:33-44. DOI: 10.1016/s0300-483x(02)00380-3.

12. Prophet E, Mills B, Arrington J, Sobin LH. Laboratory methods in histotechnology: American Registry of Pathology. Armed Forces Institute of Pathology, Washington, DC; 1992.

13. Bancroft JD, Gamble M. Theory and practice of histological techniques. $6^{\text {th }}$ Edition, 2008 Churchill Livingstone, Elsevier Health Sciences.

14. Nwangwa E, Arigi Q, Naiho A, Jeroh $E$. The effect of Cannabis sativa on testosterone level and seminal fluid analysis of male Wistar rats. Curr World Environ 2008;3:223-6.

I5. Lotfi N, Khazaei M, Shariatzadeh SMA, Mehranjani MS, Ghanbariet A. The effect of cannabis sativa hydroalcoholic extract on sperm parameters and testis histology in rats. Int J Morphol 20 I 3;3 I:82-86.

16. Banerjee A, Singh A, Srivastava $P$, Helen T, Amitabh K. Effects of chronic bhang (cannabis) administration on the reproductive system of male mice. Birth Defects Res Part B: Developmental Reproductive Toxicol 201 I;92:195205. DOI: 10.1002/bdrb.20295.

17. Mandal TK, Das NS. Effect of -9tetrahydrocannabinol on altered antioxidative enzyme defense mechanisms and lipid peroxidation in mice testes. Eur J Pharmacol 2009;607: 178-87. DOI: 10.1016/ j.ejphar.2009.01.025.
18. Machado BM, Helena Costa QR Waldo ZA, Crippa JA. Safety and side effects of cannabidiol, a Cannabis sativa constituent. Curr Drug Saf 20 I I;6:237-49.

19. Tijani A, Adekomi D, Owoyale M. Histological changes in the vital organs of male rats following short term exposure to smoke extract of Cannabis sativa. Res J Health Sci 20|4;2:90-8.

20. Yassa HA, Dawood AEWA, Shehata MM, Abdel-Hady RH, Aal KM. Subchronic toxicity of cannabis leaves on male albino rats. Hum Exp Toxicol 2010;29:37-47. DOI: 10. I I77/0960327I093543 I2.

21. Khan NA, Hasan S. Effect of Cannabis hemp (hashish) on normal and rats subjected to psychological stress.Proceedings-Animal Sciences 1984;93:121-9. DOI: 10. 1007/BF03186069

22. Reuhl J, Bachl M, Schneider M, Lutz F, Bratzke H. Morphometric assessment of testicular changes in drug-related fatalities. Forensic Sci Int 200।; | |5: |7|-8I.

\section{AUTHORS' CONTRIBUTIONS}

Following authors have made substantial contributions to the manuscript as under:

ZSK: Acquisition, analysis and interpretation of data, drafting the manuscript, final approval of the version to be published

MS: Conception \& study design, critical review, final approval of the version to be published

SMH: Analysis and interpretation of data, drafting the manuscript, final approval of the version to be published

Authors agree to be accountable for all aspects of the work in ensuring that questions related to the accuracy or integrity of any part of the work are appropriately investigated and resolved.

\begin{tabular}{|c|}
\hline CONFLICT OF INTEREST \\
Authors declared no conflict of interest \\
GRANT SUPPORT AND FINANCIAL DISCLOSURE \\
NIL
\end{tabular}

\section{DATA SHARING STATEMENT}

The data that support the findings of this study are available from the corresponding author upon reasonable request

This is an Open Access article distributed under the terms of the Creative Commons Attribution-Non Commercial 2.0 Generic License.

KMUJ web address: www.kmuj.kmu.edu.pk

Email address: kmuj@kmu.edu.pk 